\title{
Synthesis and characterization of new branched magnetic nanocomposite for loading and release of topotecan anti- cancer drug
}

\author{
Tuba Tarhan ${ }^{1}$, Bilsen Tural ${ }^{2^{*}}$ (D) and Servet Tural ${ }^{2}$
}

\begin{abstract}
The purpose of this study is to synthesize the new branched magnetic nanocomposite to carry the therapeutic agents and bio-macromolecules. Although topotecan (TPT) has significant antitumor activity to lung, ovarian, breast, pancreas, and stomach cancers, lactone ring opening causes a reduction in cytotoxic activity and severe side effects in physiological conditions. In order to contribute to the removal of the handicap (lactone ring opening), magnetic dextran branched with NaNa-Bis (carboxymethyl)-L-lysine hydrate (NTA) nanoparticles $\left(\mathrm{MD}_{3}\right)$ were prepared. The characterization of the resulting $\mathrm{MD}_{3}$ material was done by using multi-pronged analyses. The stability and release of TPT with synthesized and characterized new material of the $\mathrm{MD}_{3}$ was studied using various essential factors like concentration, dosage, $\mathrm{pH}$, and time. The entrapment efficiency and loading capacity of TPT onto $\mathrm{MD}_{3}$ was calculated as $32.2 \%$ and $1.44 \mathrm{mg} / \mathrm{g}$, respectively, at pH 5. Release studies were performed with drug-loaded $\mathrm{MD}_{3}$ at different pH values. It was seen that the best release was obtained at the cancerous site $\mathrm{pH}$. Initial drug concentration was measured as 0.118 $\mathrm{mM}$. The loaded drug concentration was calculated as $0.0380 \mathrm{mM}$ at pH 5 and $0.00092 \mathrm{mM}$ of drug was released after 90 $\mathrm{min}$ at $\mathrm{pH}$ 5.8. Percentage released of drug was found as $2.42 \%$ during 90 min.
\end{abstract}

Keywords: Drug nanocarrier, Drug release, Magnetic nanocomposite, Magnetic targeting, New branched dextran, Topotecan

\section{Introduction}

Nanomedicine, a branch of the nanotechnology, aims to repair a damaged tissue at a molecular level or treat a disease in a very specific way. In recent years, there has been an increased interest in areas involving the use of polymer-DNA complexes, polymer-drug conjugates, and polymer micelles carrying hydrophobic drugs to increase the efficiency of cancer therapy agents. Due to their small size and excellent biocompatibility, nano-sized therapeutic polymeric agents can remain in the blood stream for a long time to reach the target site. In addition, ligands that bind specifically to receptors by chemical modification of therapeutic polymeric agents can increase the interest to cancer cells. Thus, they can improve the effectiveness of the therapy significantly. Such studies summarize that

\footnotetext{
* Correspondence: bilsentural@gmail.com

${ }^{2}$ Department of Chemistry, Faculty of Education, Dicle University, Diyarbakır, Turkey

Full list of author information is available at the end of the article
}

polymeric nanomedicine will allow development of nanodrug targeting facilities and logical approaches to the characteristics of cancer in the future (Cao et al. 2011).

The level of concentration required for magnetic nanoparticles (MNPs) coated with a suitable polymer is generally below a certain toxic level in drug delivery applications (Karlsson et al. 2008). Therefore, the design of a high drug loading capacity and stable delivery systems are important. While magnetic drug delivery systems are being designed, many factors such as magnetic properties, particle sizes, and drug loading capacity need to be considered (Cao et al. 2011).

Polymeric nanoparticles compared with the structure of colloidal carrier are more stable in biological fluids, provide sustained drug release, and some of the advantages of the polymer (Schweiger et al. 2011; Zhou et al. 2011). In recent years, it is noteworthy that biodegradable polymeric nanoparticles can be applied to the targeted organ or tissue in the distribution of drugs and 
can be used as a DNA carrier in gene therapy (Gaucher et al. 2005; Lee et al. 2005; Neuberger et al. 2005; Ogris and Wagner 2002; Park et al. 2008; Torchilin 2002; Thomas 2010).

Natural and synthetic polymers are used for preparing the polymeric nanoparticles. The natural polymers are composed of two groups: proteins (albumin, gelatin, etc.) and polysaccharides (alginate, chitosan, dextran, etc.). Synthetic polymers are composed of pre-synthesized polymers (polyanhydrides, polycaprolactone-PCL, poly (lactic acid)-PLA, poly (lactic-co-glycolic acid)-PLGA, etc.) or polymers during preparation (poly (cyanoacrylate)-PACA, etc.) (Ak 2010). Natural polymers are preferred because of their biodegradability, ability to be metabolized, stability and controllable size distribution, and high loading capacity for water-soluble drugs (Park et al. 2005).

Dextran is one of the macromolecules that contain glucose from simple monosaccharides. It is commonly used for the conjugation of anticancer drugs. This biopolymer containing polyglucose, it is at the head of the polymers that are to be studied in drug delivery systems because of its plasma-expanding properties, desirable physicochemical properties, low cost of ownership, and attractive clinical traits. In the study by Singh et al., uncoated magnetite, uncoated maghemite, dextran-coated magnetite, and dextrancoated maghemite particles were studied comparatively in terms of cytotoxicity and were seen that the samples did not show cytotoxicity under $100 \mathrm{mg} / \mathrm{mL}$ (Singh et al. 2012; Lee et al. 2011; Pisanic et al. 2007). Dextran biopolymer and derivatives are widely used for in the biomedical applications and chemical conjugation because of their excellent properties such as water solubility, biodegradability, biocompatibility, and non-fouling (McIntosh et al. 1997; Shahnaz et al. 2010; Sun et al. 2010; Thambi et al. 2014). Especially carboxymethyl dextran (CMD) has several functional groups (hydroxyl, carboxyl, and aldehyde at the end of the chain). Due to these functional groups, the CMDdrug conjugates have been geared up. The drugs can be released by degradation of the polymers (McIntosh et al. 1997; Thambi et al. 2014).

Recently, especially carboxymethyl dextran is the most preferred dextran derivatives in drug delivery systems as they form cytotoxic drug conjugates. Carboxymethyl dextran through that having carboxyl groups provides an effective conjugation with the polymer-drug interaction. These conjugate have generally a long-term effect and reduced toxicity in many in vivo and in vitro studies. Based on this information, a better polymer-drug conjugation provides by increasing the active carboxyl groups on the surface (Goodarzi et al. 2013; Lee et al. 2004; Mert et al. 2012; Xie et al. 1999; Zhang et al. 2007; Zhu et al. 2009).

Rodriguez-Luccioni et al. synthesized magnetic carboxymethyl dextran. They examined the cytotoxicity properties of these particles and tested them on human epithelium colorectal adenocarcinoma (Caco-2) and human breast cancer (MCF-7) cells. They also investigated the effects of these particles on the cell viability by applying the magnetic fluid hyperthermia and hot-water hyperthermia properties on to the model of two cancer cells (Rodriguez-Luccioni et al. 2011).

Harada et al. have shown that camptothecin (CPT) derivatives, irinotecan (CPT-11), and topotecan (TPT), which are widely used clinically in spite of toxicity, are the most promising classification of anti-tumor agents. They have synthesized denoted T-0128 to improve the pharmacological profile of the new macromolecular prodrug. This pro-drug which has a molecular weight of $\mathrm{Mr}$ 130,000 is conjugated to a novel CPT analog (T-2513) carboxymethyl $(\mathrm{CM})$ dextran via triglyceride (Harada et al. 2000).

TPT, which is the most widely used anticancer drug, is a CPT analog and is acting as topoisomerase I inhibitor (Pommier 2006; Pommier et al. 2010). This enzyme is responsible for DNA replication during cell division (Staker et al. 2002; Bertrand et al. 1994). TPT is used effectively in the treatment of mainly ovarian cancer and small-cell lung cancer and also used for the treatment of breast cancer and prostate cancer. The structure of TPT contains the $\alpha$-hydroxy $\delta$-lactone ring and is a good soluble in water. Active lactone form is prepotent under acidic conditions. It is hydrolyzed to the carboxylate form at the neutral and alkaline $\mathrm{pH}$. At physiological $\mathrm{pH}$ (7.4), the lactone ring is opened reversibly and the equilibrium is favored in the carboxylate form. The carboxylate form is penetrated less by the cells and is bound at 98\% of human serum albumin (HSA) at physiological $\mathrm{pH}$. The opening of lactone ring results in loss of activity and high toxic effects.

Mert et al. have shown that the lactone ring opening (Ering, as seen in Scheme 1) can facilitate under physiological and base conditions due to the stabilization of the transition state via strong intramolecular hydrogen bonding between $20-\mathrm{OH}$ and acyl carbon. To preclude this phenomenon, it is taken advantage of intermolecular hydrogen bonding between the 20-OH groups of the lactone ring and carbonyl groups of the lactide units in the PLLA-mPEG diblock copolymer. So, it is most likely reduced intramolecular hydrogen bonding within the lactone ring of the TPT (Mert et al. 2012; Fugit and Anderson 2014). The purpose of this study is to synthesize the new branched carboxymethyl dextran magnetic nanocomposite with $\mathrm{N \alpha N \alpha -Bis} \mathrm{(carboxymethyl)-L-}$ lysine hydrate (NTA) suitable for carrying the therapeutic agents and bio-macromolecules (e.g., drug, enzyme, antibody, DNA), having magnetic, chemical, and physical properties in order to use effectively drug loading and release studies. By increasing - $\mathrm{COOH}$ groups on the surface, it can be ensured that the molecules are more easily and effectively bonded to the surface. In addition, superparamagnetic nanocomposite 

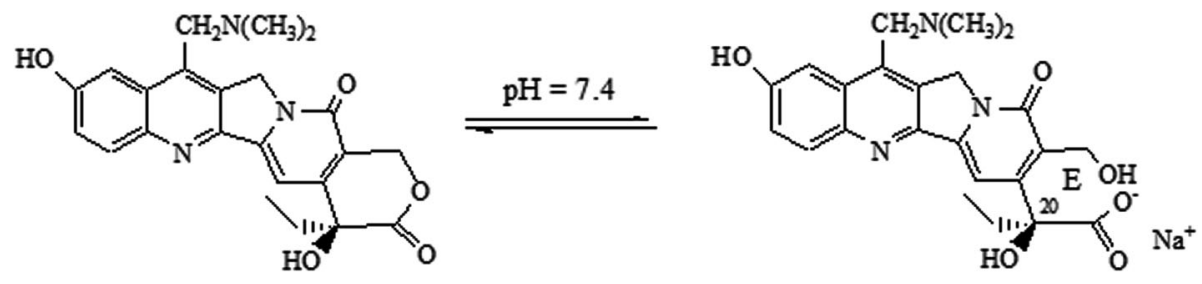

Scheme 1 Proposed mechanism of the conversion of the lactone ring to the carboxylate form of TPT

can be carried to the target area in a short time with an external magnetic field. In this study, firstly magnetic nanoparticles were coated with dextran polymer thus magnetic dextran $\left(\mathrm{MD}_{1}\right)$ was obtained. Then magnetic O-carboxymethyl dextran $\left(\mathrm{MD}_{2}\right)$ was synthesized from $\mathrm{MD}_{1}$. Finally, the synthesis of new branched carboxymethyl dextran magnetic nanocomposite $\left(\mathrm{MD}_{3}\right)$ with NTA was generated from $\mathrm{MD}_{2}$. Secondly, it was studied on drug loading and release conditions for anti-cancer drug topotecan.

\section{Materials and Methods Materials}

$\mathrm{FeCl}_{2} \cdot 4 \mathrm{H}_{2} \mathrm{O}$ (purists. p.a., $\geq 99.0 \%$ RT, Sigma-Aldrich) and $\mathrm{FeCl}_{3} \cdot 6 \mathrm{H}_{2} \mathrm{O}$ (ACS reagent, 97\%, Sigma-Aldrich) were used for the synthesis of $\mathrm{Fe}_{3} \mathrm{O}_{4} \cdot \mathrm{NH}_{3}$ (anhydrous, $\geq 99.98 \%$, Aldrich) was used for precipitation in the basic medium during synthesis of $\mathrm{Fe}_{3} \mathrm{O}_{4}$. Dextran 70 (United States Pharmacopeia (USP)) was provided for synthesis dextran-coated iron oxide nanoparticles. Bromoacetic acid (reagent grade, 97\%, Aldrich) was taken for synthesis of O-carboxymethyl dextran from dextran polymer. New branched carboxymethyl dextran was synthesized by using $N$-(3-dimethyl aminopropyl)- $N$-ethyl carbodiimide hydrochloride (EDC) ( $\geq 98 \%$, Aldrich), $N$-hydroxysuccinimide (NHS) (98\%, Aldrich), and NTA ( $\geq 97.0 \%$ (TLC) (Aldrich) based on O-carboxymethyl dextran. MES hydrate ( $\geq 99.5 \%$ (titration) (Sigma)) was used to solve reactant in the synthesis stage. Isopropanol and Ethanol were used in the synthesis and washing processes. Acetic acid (Glacial) (Merck 100\%) was provided for the $\mathrm{pH}$ adjustment of the mobile phase used in highperformance liquid chromatography (HPLC). Sodium hydroxide $(\mathrm{NaOH})$ and hydrochloric acid $(\mathrm{HCl})$ were used to adjust the $\mathrm{pH}$. Acetonitrile (Chromasolv SigmaAldrich) was provided for the HPLC mobile phase. Phosphate buffer saline (Sigma 100 Tablet) was used for drug loading and release studies. Triethyl amine (99\% SigmaAldrich) was used to prepare triethyl amine acetate buffer. Topotecan (Sigma) is an anti-cancer drug.

\section{Methods}

\section{The techniques used in the characterization of samples}

Fourier-transform infrared spectroscopy (FT-IR), transmission electron microscopy (TEM), scanning electron microscope (SEM), energy dispersive $\mathrm{X}$-ray analysis (EDX), X-ray photoelectron spectroscopy (XPS), and vibrating sample magnetometer (VSM) analysis techniques were used for elemental analysis, size and surface morphology, structural analysis, and magnetic characterization of synthesized nanocomposite. All of the drug loading and release studies were analyzed by HPLC.

FT-IR analyses were made with Thermo Scientific Nicolet 95 IS10 FT-IR spectrometer device. VSM analysis was made with Cryogenic Limited PPMS device. TEM analyses were made with JEOL mark JEM 2100F model transmission electron microscopy. SEM and EDX analyses were made with QUANTA 400F Field Emission SEM high-resolution scanning electron microscope. XPS analyses were made with PHI 5000 Versa Probe device. HPLC analyses were made with Agilent Technologies 1260 Infinity HPLC.

\section{The synthesis of $M D_{3}$ with NTA}

A series of reactions are necessary for $\mathrm{MD}_{3}$ synthesis, all of which are given below. Firstly, $30 \mathrm{~mL}$ of deionized water was placed in a $250 \mathrm{~mL}$ three-necked round bottom flask in an $\mathrm{N}_{2}$ gas atmosphere. Then, 1:2 mole ratio $(0.86 \mathrm{~g} / 2.36 \mathrm{~g}) \mathrm{FeCl}_{2} \cdot 4 \mathrm{H}_{2} \mathrm{O} / \mathrm{FeCl}_{3} \cdot 6 \mathrm{H}_{2} \mathrm{O}$ iron salts was completely dissolved with a mechanical stirrer. Further, $200 \mathrm{mg}$ dextran dissolved in $20 \mathrm{~mL}$ deionized water was added to this mixture and stirred in an oil bath under the reflux up to $80^{\circ} \mathrm{C}$. After then, $28 \% 1.2 \mathrm{~mL} \mathrm{NH}_{3}$ solution was added dropwise to the reaction medium and provided precipitation of $\mathrm{MD}_{1}$. The system was stirred with a mechanical stirrer for $1 \mathrm{~h}$ after then closed. The suspension mixture was precipitated with the aid of an external magnet and washed 3-4 times with deionized water (Hong et al. 2008; Li et al. 2011). The synthesized $\mathrm{MD}_{1}(0.16 \mathrm{~g})$ was thoroughly dispersed in deionized water with a sonicator and stirred with a mechanical stirrer for a few minutes. Then, 0.1 molar bromoacetic acid $(1 \mathrm{mmol})$ was dissolved in $10 \mathrm{~mL} 2$ molar $\mathrm{NaOH}$ solution and added on this suspension. It was stirred with a mechanical stirrer for $24 \mathrm{~h}$. The suspension mixture was precipitated with the aid of an external magnet and $\mathrm{MD}_{2}$ was synthesized. It was washed with deionized water and the filtrate was discarded. The schematic 
representation of the reaction steps were given in Fig. 1 (Li et al. 2011; Han et al. 2010).

In the previous step, synthesized $\mathrm{MD}_{2}$ was thoroughly dispersed in deionized water with a sonicator. Then, $240 \mathrm{mg}$ EDC and $1060 \mathrm{mg}$ NHS were dissolved in $2.5 \mathrm{~mL}$ MES hydrate buffer which had previously been adjusted to $\mathrm{pH}$ value of 4.5 and added on the dispersion. The mixture was incubated at $200 \mathrm{rpm}$ for $1 \mathrm{~h}$ at a laboratory temperature. After 1 $h$, the unreacted EDC and NHS were removed by washing three or four times with MES hydrate buffer at $\mathrm{pH}$ 6. After that, $0.3 \mathrm{~g} \mathrm{NaCl}$ and $3 \mathrm{~g}$ NTA were dissolved in MES hydrate buffer at pH 6 and added in the mixture. The mixture was stirred by vortex for $2 \mathrm{~s}$ and was kept for $2 \mathrm{~h}$ at laboratory temperature. After $2 \mathrm{~h}$, the obtained $\mathrm{MD}_{3}$ was washed with MES hydrate buffer at $\mathrm{pH} 6$ and then with deionized water several times. The schematic representation of reaction steps were given in Fig. 2 (Tural et al. 2008; Mojarradi 2011).

\section{Topotecan loading studies on the $\mathrm{MD}_{3}$ nanocomposite} In this study, $1 \mathrm{mM}$ and $2 \mathrm{mM}$ Topotecan stock solutions were prepared in dimethyl sulfoxide (DMSO) for drug loading studies. TPT loading studies were carried out by the synthesized $\mathrm{MD}_{3}$ nanocomposite and the drug loading efficiency of $\mathrm{MD}_{3}$ was determined. In this study, the effect of $\mathrm{pH}$, interaction time between the drug and surface, the concentration of drug and the dose of nanocomposite on loading efficiency were investigated. In drug loading study,

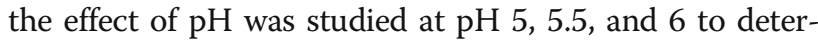
mine the optimum $\mathrm{pH}$ values depending on time. Then, $0.118 \mathrm{mM}$ TPT was prepared from the stock solution 1 $\mathrm{mM}$ and dissolved in $2 \mathrm{~mL}$ phosphate buffer which was interacted with $25 \mathrm{mg}$ nanocomposite in the incubator at $200 \mathrm{rpm}$ and $25^{\circ} \mathrm{C}$. The percentage of drug loading was calculated using the following Eq. (1) at each pH value.

Drug loading efficiency\%
$=\frac{\text { Initial drug concentration }(\mathrm{mM}) \text {-Supernatant drug concentration }(\mathrm{mM})}{\text { Initial drug concentration }(\mathrm{mM})}$

The influence of biosorbent dosage was studied varying the nanocomposites mass from 1 to $25 \mathrm{mg}$ and the

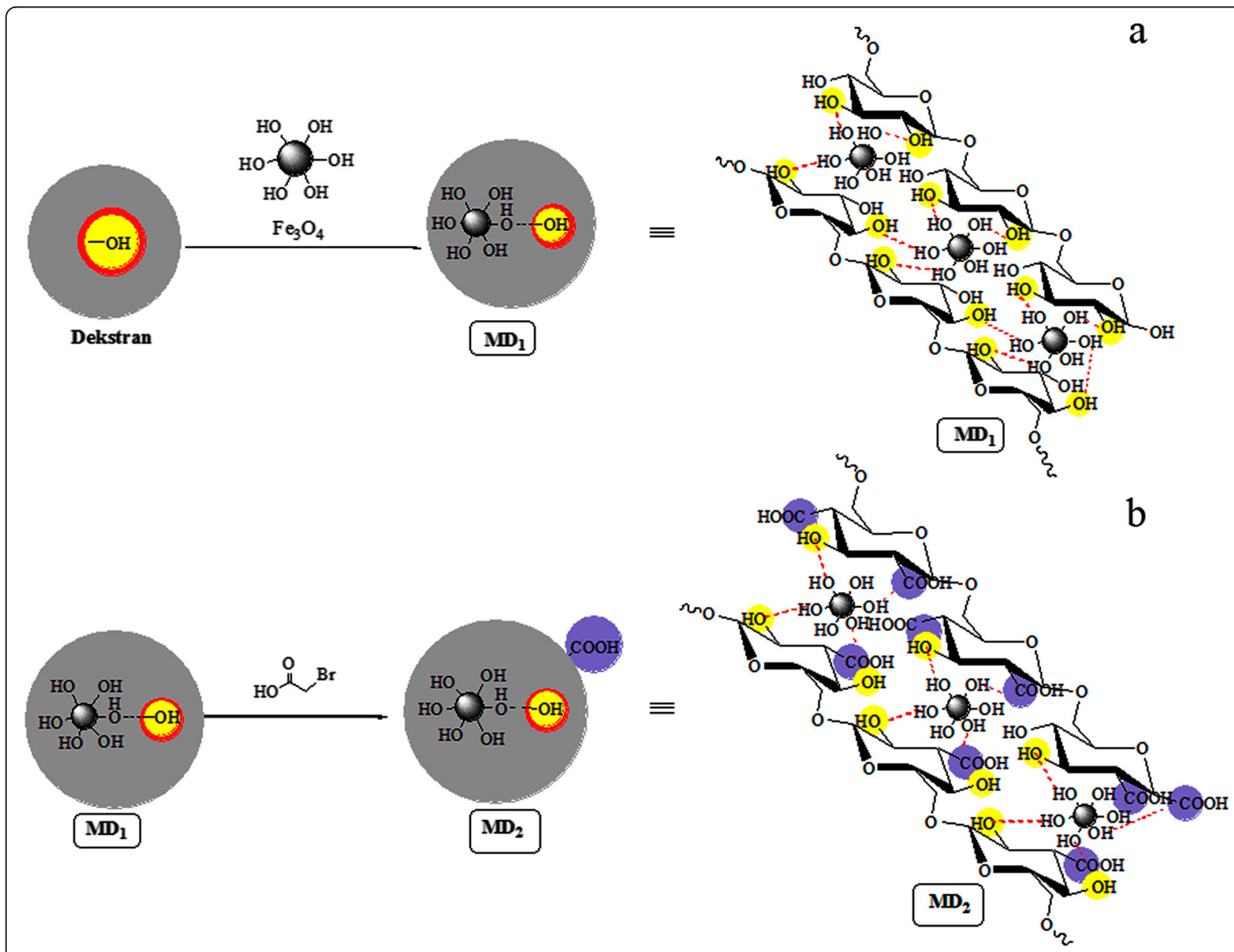

Fig. 1 The reaction steps for the synthesis of $M D_{1}$ and $M D_{2}$ 


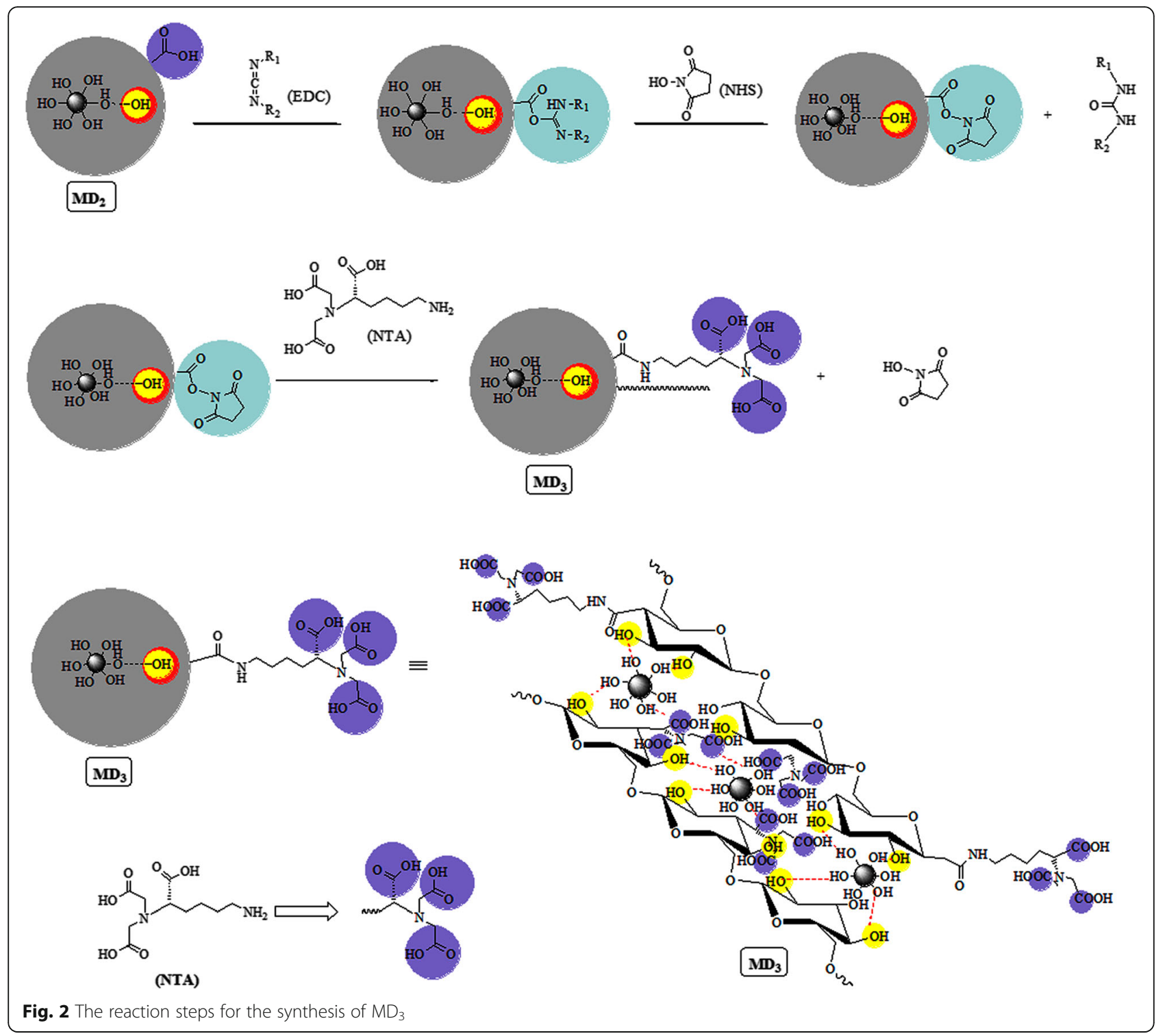

wet nanocomposite was used in experiments. These amounts of nanocomposite were interacted with 0.118 $\mathrm{mM}$ TPT in $2 \mathrm{~mL}$ phosphate buffer at $\mathrm{pH} \mathrm{5,} 200 \mathrm{rpm}$ and $25^{\circ} \mathrm{C}$.

Furthermore, three different concentrations of TPT and $15 \mathrm{mg}$ nanocomposite were interacted in $2 \mathrm{~mL}$ phosphate buffer at $\mathrm{pH} 5,200 \mathrm{rpm}$, and $25^{\circ} \mathrm{C}$ to examine the effect of drug concentration on loading efficiency depending on time.

\section{Drug release studies}

Drug release studies were carried out with drug-loaded $\mathrm{MD}_{3}$ at different $\mathrm{pH}$ values and depending on time. The $\mathrm{pH}$ values in literature were taken into consideration in drug release studies (Danhier et al. 2010). Therefore, the release studies were carried out at $\mathrm{pH}$ values of 5.8, 6.5, and 7.4. All of the studies were conducted in phosphate- buffered medium. The percentages of the release were calculated at different $\mathrm{pH}$ values according to the following Eq. (2).

$$
\text { Drug release } \%=\frac{\text { Drug in the medium }(\mathrm{mM})}{\text { Drug entrapment }(\mathrm{mM})} \times 100
$$

\section{Result and Discussion Characterizations}

The FT-IR spectrum of $\mathrm{Fe}_{3} \mathrm{O}_{4}$ nanoparticles and $\mathrm{MD}_{1}$ nanocomposite were given in Fig. 3a. The broad absorption band of the $\mathrm{O}-\mathrm{H}$ stretching vibration at $3400 \mathrm{~cm}^{-1}$, $\mathrm{H}-\mathrm{O}-\mathrm{H}$ vibrations at around $1610 \mathrm{~cm}^{-1}, \mathrm{O}-\mathrm{H}$ bending vibrations at $1390 \mathrm{~cm}^{-1}$, and characteristic Fe-O peak at $540 \mathrm{~cm}^{-1}$ were shown in the Fig. $3 \mathrm{a}$ for $\mathrm{Fe}_{3} \mathrm{O}_{4}$ 


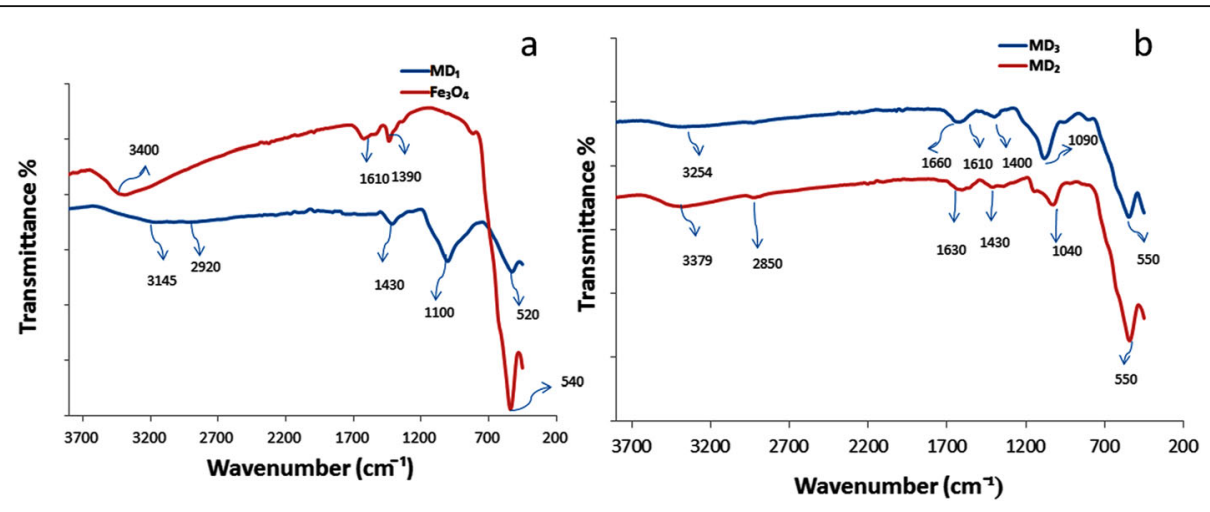

Fig. 3 The FTIR spectrums of $\mathrm{Fe}_{3} \mathrm{O}_{4}$ and $M D_{1}$ (a). The FTIR spectrums of $\mathrm{MD}_{2}$ and $\mathrm{MD}_{3}$ (b)

nanoparticles (Kim et al. 2001; Liu et al. 2009). In addition, the spectrum of $\mathrm{MD}_{1}$ was shown in Fig. 3a. The broad peak of $-\mathrm{O}-\mathrm{H}$ group at $3145 \mathrm{~cm}^{-1}$, the stretching peak of $-\mathrm{C}-\mathrm{H}$ at $2920 \mathrm{~cm}^{-1}$, the $-\mathrm{C}-\mathrm{H}$ bending vibration at $1430 \mathrm{~cm}^{-1}$, the alcoholic hydroxyl (-C-O) stretching vibration at $1100 \mathrm{~cm}^{-1}$, and the $\mathrm{Fe}-\mathrm{O}$ band at $520 \mathrm{~cm}^{-1}$ were observed in the spectrum of $\mathrm{MD}_{1}$ (Dumitraşcu et al. 2011; Khalkhali et al. 2015; Koneracká et al. 2010). The FT-IR spectrums of $\mathrm{MD}_{2}$ and $\mathrm{MD}_{3}$ were given in Fig. $3 \mathrm{~b}$. As can be seen in Fig. 3b, the characteristic -O-H stretching peak at $3379 \mathrm{~cm}^{-1}$ and $-\mathrm{C}-\mathrm{H}$ stretching at $2850 \mathrm{~cm}^{-1}$ were demonstrated. The carboxylic acid peak $(-\mathrm{C}=\mathrm{O})$ was given at $1630 \mathrm{~cm}^{-1}$ for $\mathrm{MD}_{2}$ nanocomposite. This characteristic $-\mathrm{C}=\mathrm{O}$ peak was found on $\mathrm{MD}_{2}$ spectrum but not found on $M D_{1}$ spectrum. This is the evidence of that $M_{2}$ was successfully synthesized. It was determined that the deformed $-\mathrm{CH}_{2}$ stretching peak at $1430 \mathrm{~cm}^{-1}$, the alcoholic hydroxyl -C-O stretching was shown at $1040 \mathrm{~cm}^{-1}$, and the
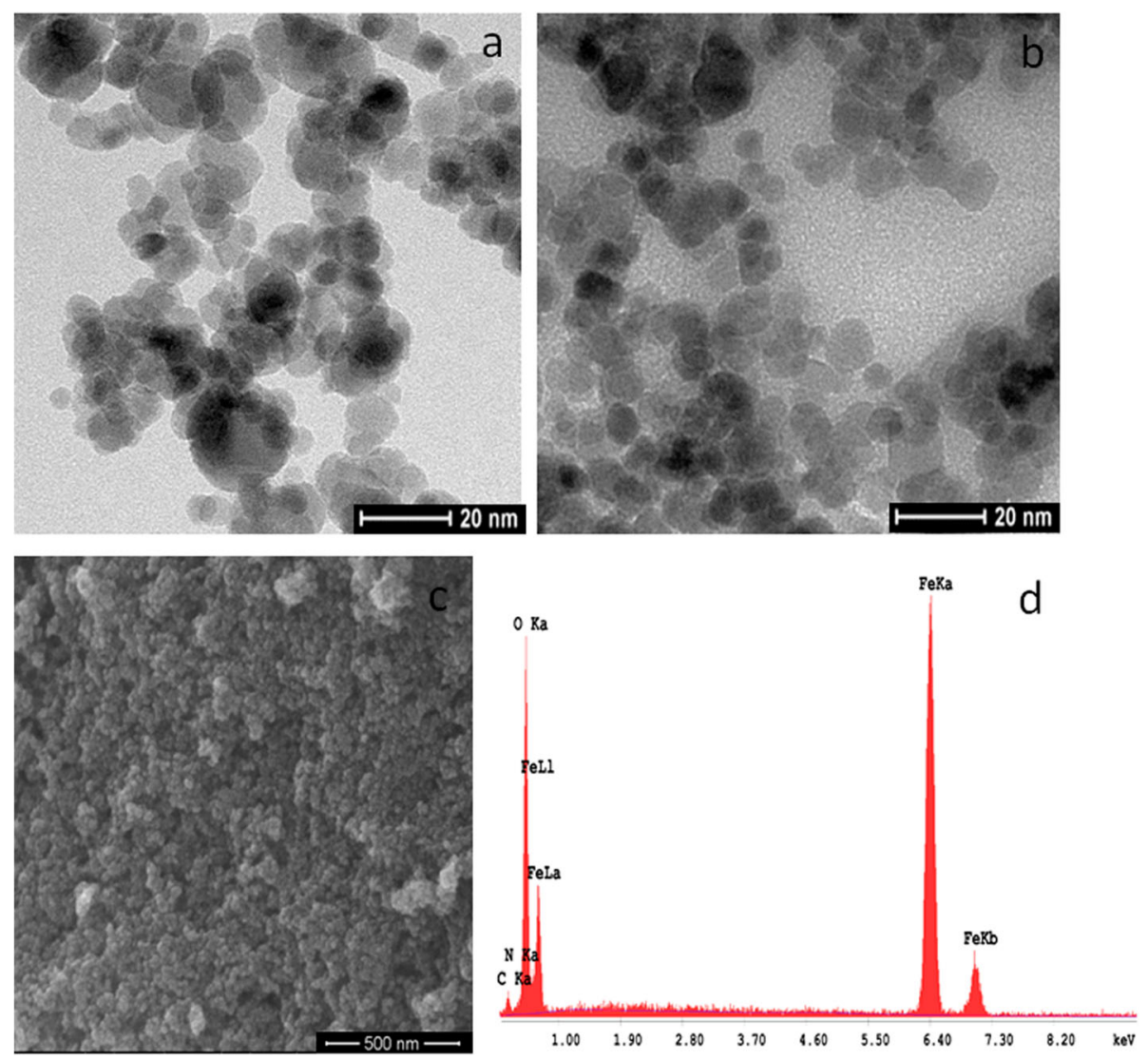

Fig. 4 TEM images of the $\mathrm{Fe}_{3} \mathrm{O}_{4}(\mathbf{a})$ and $\mathrm{MD}_{3}$ (b). SEM image of the $\mathrm{MD}_{3}(\mathbf{c})$ and EDX spectrum of the $\mathrm{MD}_{3}(\mathbf{d})$ 


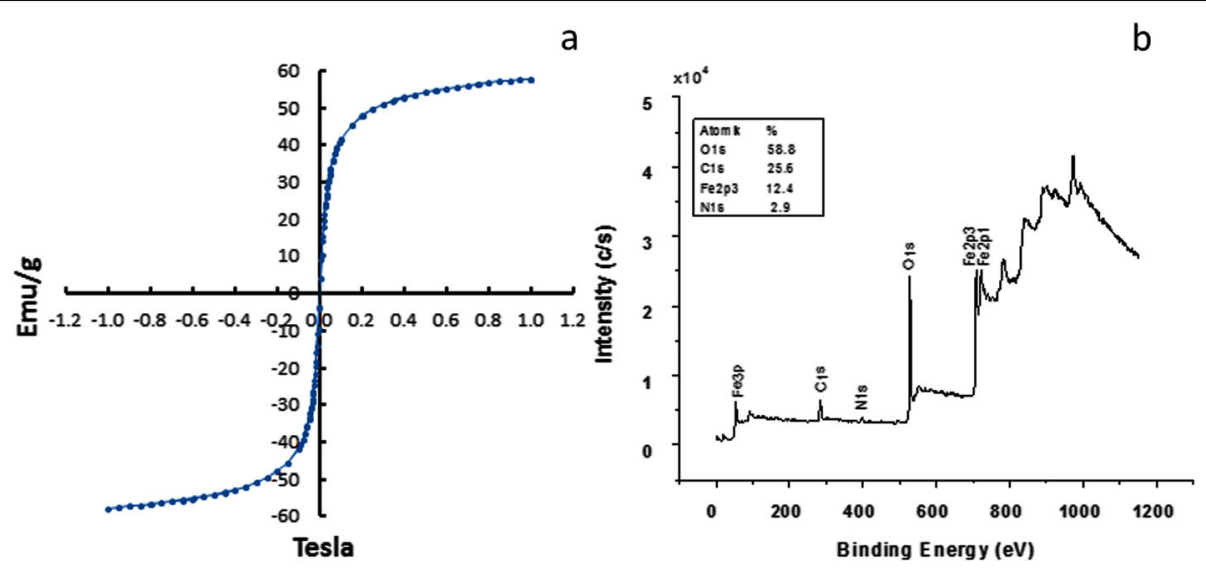

Fig. 5 Magnetization curve versus the magnetic field (a) and XPS wide scan spectrum (b) for the $\mathrm{MD}_{3}$ nanocomposite

characteristic Fe-O peak was given at $550 \mathrm{~cm}^{-1}$ for $\mathrm{MD}_{2}$ nanocomposite (Ayala et al. 2013; Creixell et al. 2010). On the other hand, the FT-IR spectrum of $\mathrm{MD}_{3}$ was given in Fig. 3b. In the figure, the characteristic $-\mathrm{O}-\mathrm{H}$ stretching peak at $3254 \mathrm{~cm}^{-1}$ was shown for $\mathrm{MD}_{3}$. The bands at 1660 $\mathrm{cm}^{-1}$ and $1610 \mathrm{~cm}^{-1}$ anticipated the presence of functional groups of amide I $(-\mathrm{C}=\mathrm{O})$ and amide II respectively. The symmetrical carboxylic acid stretching vibration peak was indicated at $1400 \mathrm{~cm}^{-1}$. The peak at $1090 \mathrm{~cm}^{-1}$ was represent in -C-O alcoholic hydroxyl stretching and at $550 \mathrm{~cm}^{-1}$

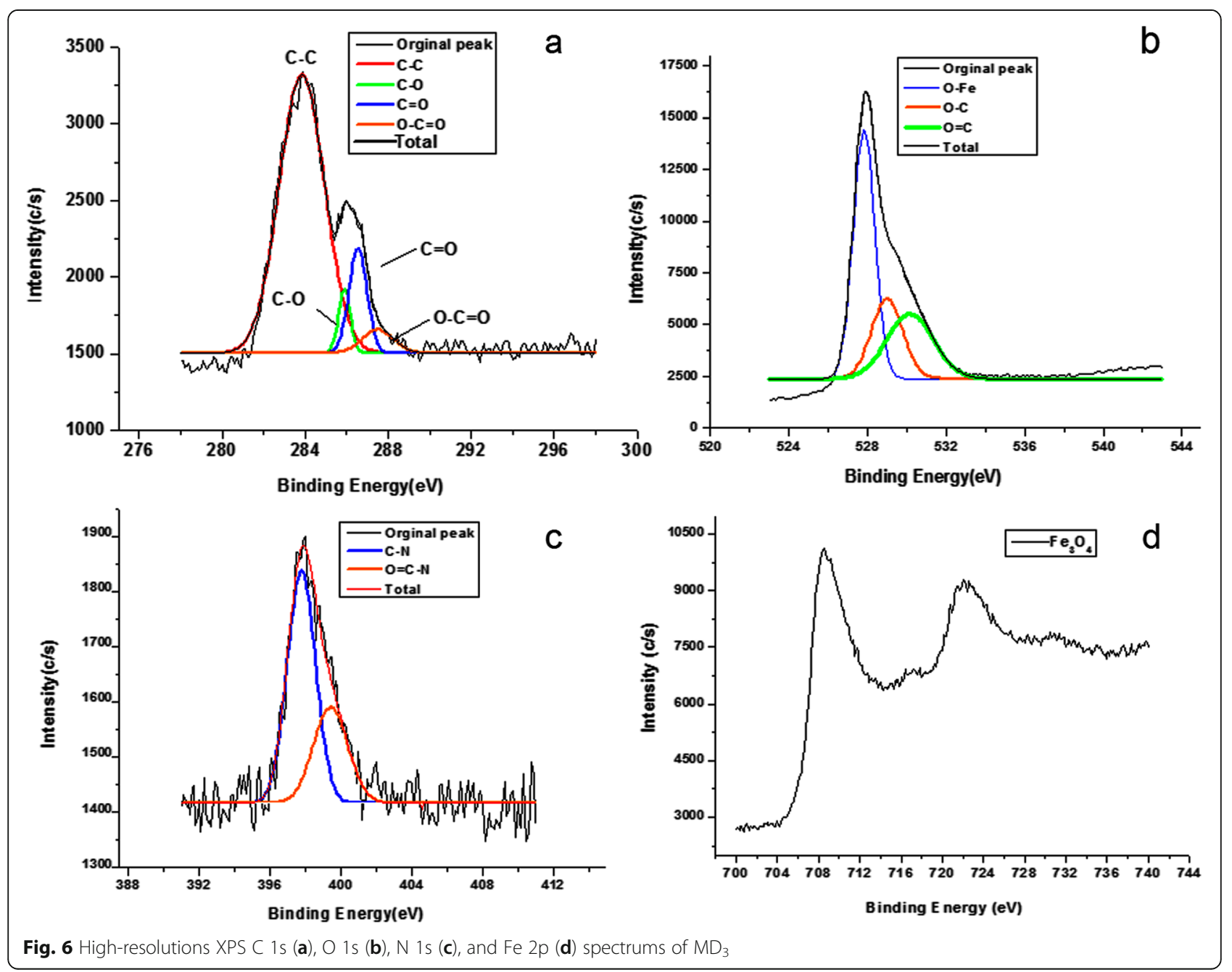


was demonstrated the characteristic Fe-O peak for $\mathrm{MD}_{3}$ nanocomposite (Aguirre et al. 2014; Andersson et al. 2007; Kaya and Mr 2012; Souaya et al. 2000).

TEM images were taken to get information about the morphology and dimensions of the synthesized nanoparticles and the nanocomposite. As can be seen in Fig. 4a, b, the particles showed a spherical structure for $\mathrm{Fe}_{3} \mathrm{O}_{4}$ (a) and $\mathrm{MD}_{3}$ (b). TEM images also showed that the particle sizes of $\mathrm{Fe}_{3} \mathrm{O}_{4}$ and $\mathrm{MD}_{3}$ were about $10 \pm 3.6 \mathrm{~nm}$ and $8 \pm 2.1 \mathrm{~nm}$ respectively at $20 \mathrm{~nm}$ scale in Fig. $4 \mathrm{~b}$. Furthermore, TEM image of $\mathrm{MD}_{3}$ showed that the particle sizes decreased with the coating and better dispersed. SEM image of $\mathrm{MD}_{3}$ was given in Fig. 4c. As understood from the image, there was no clear information about the surface morphology due to the very small particle sizes. Also, the measurement result of EDX was shown in Fig. $4 \mathrm{~d}$ for $\mathrm{MD}_{3}$. It was successfully synthesized when looking at the atomic content, and also no significant impurity was found in the sample.

The magnetization value of the synthesized nanocomposite was measured by the change of the magnetic field versus magnetization at ambient condition. In our previous study, the magnetic saturation value of $\mathrm{Fe}_{3} \mathrm{O}_{4}$ was measured as the $68 \mathrm{emu} / \mathrm{g}$ (Tarhan et al. 2015). However, MNPs coated with polymer caused a decrease in magnetic saturation. This reduction is due to the fact that the superparamagnetic particles are coated with the diamagnetic polymer and therefore the mass values of the particles cannot be accurately measured. However, the surface area increased as the particle size decreased and the magnetic saturation values decreased due to the spin distortions on the surfaces (Lee et al. 2005). As a result, the relative magnetization values of the particles are reduced depending on the particle size and the coating percentage. In Fig. 5a, the magnetization value of the $\mathrm{MD}_{3}$ nanocomposite was measured as 55.7 $\mathrm{emu} / \mathrm{g}$. It was found ideal value for drug delivery systems. Also, $\mathrm{MD}_{3}$ was characterized with general spectrum by using XPS in Fig. 5b. The observation of chemical bonds in this spectrum were used for clarification of the structures. The atomic percent of $\mathrm{C}$ $(1 \mathrm{~s}), \mathrm{O}(1 \mathrm{~s}), \mathrm{Fe}\left(2 \mathrm{p}^{3}\right)$, and $\mathrm{N}(1 \mathrm{~s})$ were measured as $25.6 \%, 58.8 \%, 12.4 \%$, and $2.9 \%$ respectively for $\mathrm{MD}_{3}$ nanocomposite.

In the high-resolution spectrum of $\mathrm{C}(1 \mathrm{~s})$, the peaks at $\sim 284.4, \sim 286.4, \sim 287.1$, and $\sim 288.7 \mathrm{eV}$ were attributed to $\mathrm{C}-\mathrm{C}, \mathrm{C}-\mathrm{O}, \mathrm{C}-\mathrm{N}$, and $\mathrm{NH}-\mathrm{C}=\mathrm{O}$, respectively in Fig. 6a (Wang et al. 2014; Zhang et al. 2016). Also, the O (1s) spectrum should be fitted with three peaks at $~ 528.0, \sim$ 530.5 , and $\sim 531.5 \mathrm{eV}$, corresponding to the $\mathrm{O}-\mathrm{Fe}, \mathrm{O}-\mathrm{C}$, and $\mathrm{O}=\mathrm{C}$ bonds, respectively, as shown in Fig. 6b (Chellouli et al. 2016; Zheng et al. 2016).

As shown in Fig. 6c, the peaks of $\mathrm{C}-\mathrm{N}$ bond and $\mathrm{O}=\mathrm{C}-$ $\mathrm{N}$ bond were observed at $\sim 398.1 \mathrm{eV}$ and at $\sim 402 \mathrm{eV}$ binding energy, respectively in the high-resolution

Table 1 The result of topotecan loading studies on the $M_{3}$

\begin{tabular}{|c|c|c|c|c|c|}
\hline $\mathrm{pH}$ & Time (min) & Lactone(mM) & Carboxylate(mM) & Loaded drug $(\mathrm{mM})^{\mathrm{a}} \pm \mathrm{SD} .^{\mathrm{b}}$ & Loading capacity $(\mathrm{mg} / \mathrm{g})$ \\
\hline \multirow[t]{6}{*}{5} & 0.5 & 0.0788 & 0 & $0.0392 \pm 0.0017$ & 1.44 \\
\hline & 1 & 0.0768 & 0.0047 & $0.0365 \pm 0.0012$ & 1.34 \\
\hline & 2 & 0.0751 & 0.0049 & $0.0379 \pm 0.0020$ & 1.39 \\
\hline & 3 & 0.0738 & 0.0052 & $0.0390 \pm 0.0011$ & 1.43 \\
\hline & 4 & 0.0723 & 0.0059 & $0.0398 \pm 0.0018$ & 1.46 \\
\hline & 5 & 0.0704 & 0.0062 & $0.0414 \pm 0.0019$ & 1.52 \\
\hline \multirow[t]{6}{*}{5.5} & 0.5 & 0.0659 & 0 & $0.0521 \pm 0.0023$ & 1.91 \\
\hline & 1 & 0.0636 & 0.0065 & $0.0479 \pm 0.0018$ & 1.75 \\
\hline & 2 & 0.0617 & 0.0067 & $0.0496 \pm 0.0019$ & 1.82 \\
\hline & 3 & 0.0594 & 0.0071 & $0.0515 \pm 0.0023$ & 1.89 \\
\hline & 4 & 0.0585 & 0.0074 & $0.0521 \pm 0.0030$ & 1.91 \\
\hline & 5 & 0.0570 & 0.0077 & $0.0534 \pm 0.0026$ & 1.96 \\
\hline \multirow[t]{6}{*}{6} & 0.5 & 0.0498 & 0 & $0.0682 \pm 0.0020$ & 2.50 \\
\hline & 1 & 0.0467 & 0.0089 & $0.0624 \pm 0.0020$ & 2.29 \\
\hline & 2 & 0.0423 & 0.0094 & $0.0663 \pm 0.0018$ & 2.43 \\
\hline & 3 & 0.0389 & 0.0097 & $0.0694 \pm 0.0019$ & 2.54 \\
\hline & 4 & 0.0373 & 0.0117 & $0.0690 \pm 0.0021$ & 2.53 \\
\hline & 5 & 0.0362 & 0.0165 & $0.0653 \pm 0.0022$ & 2.39 \\
\hline
\end{tabular}

${ }^{\mathrm{a}}$ Mean

${ }^{\mathrm{b}}$ Standard deviation $(n=3)$ 


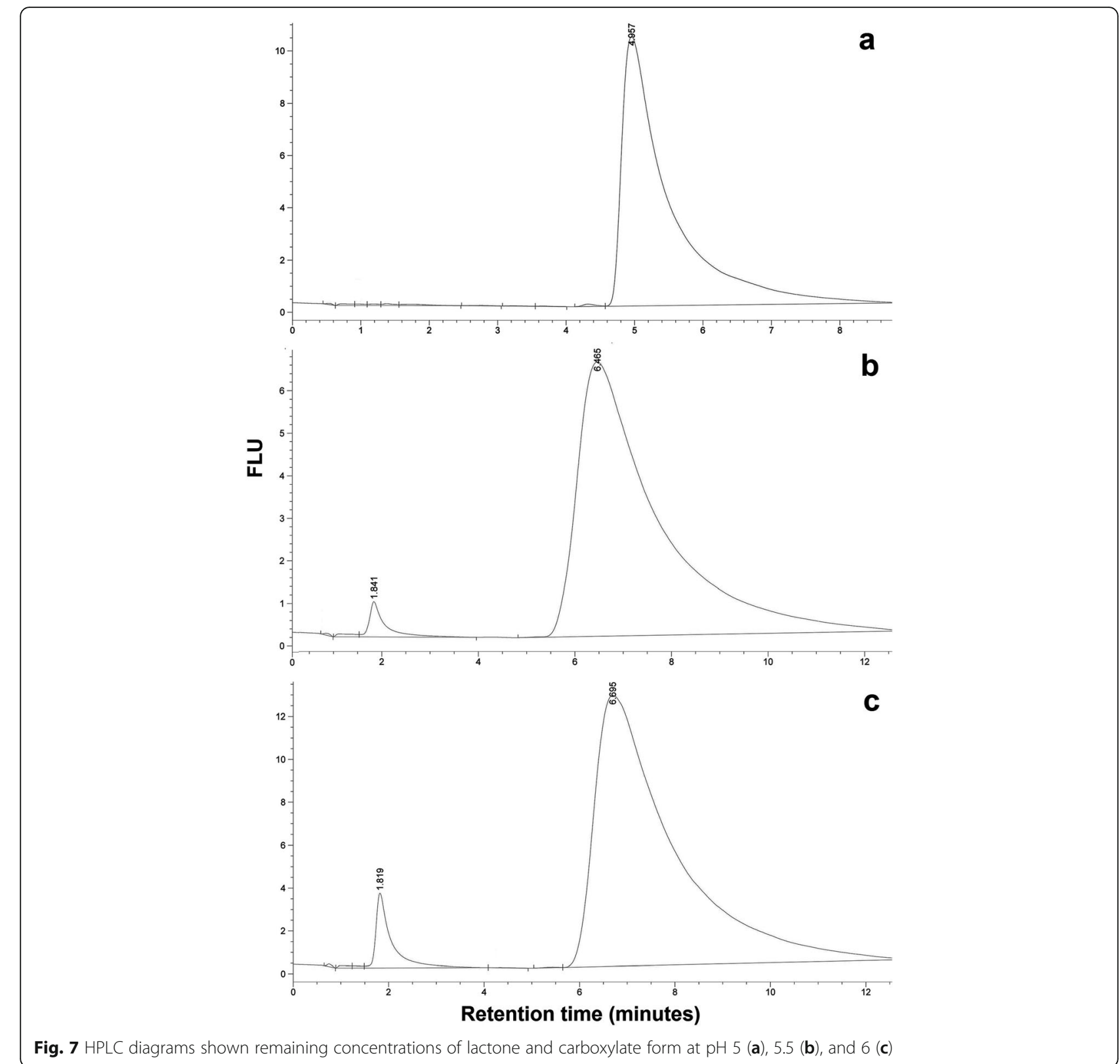

spectrum of $\mathrm{N}$ (1s) (Zhang et al. 2016). In the spectrum of Fe $2 \mathrm{p}$ (Fig. $6 \mathrm{~d}$ ), the peaks of Fe $2 \mathrm{p}_{3 / 2}$ and Fe $2 \mathrm{p}_{1 / 2}$ were located at $\sim 709.2$ and $\sim 722.8 \mathrm{eV}$, respectively for the typical structure of $\mathrm{Fe}_{3} \mathrm{O}_{4}$. One of the two peaks represents the presence of $\mathrm{Fe}^{2+}$ ions $(\mathrm{FeO})$ and the other $\mathrm{Fe}^{3+}$ ions $\left(\mathrm{Fe}_{2} \mathrm{O}_{3}\right)$. The results were found to be consistent with the literature (Anderson et al. 1996; Godo et al. 2016; Nath et al. 2009; Unsoy et al. 2012; Wu et al. 2010; Xing et al. 2015; Zhang et al. 2012). The general and high-resolution spectrums of XPS showed that the $\mathrm{MD}_{3}$ nanocomposite was successfully synthesized.

Table 2 The results of loaded drug and drug entrapment efficiency \% on the $\mathrm{MD}_{3}$ (each experiment was studied in triplicate)

\begin{tabular}{llll}
\hline Nanocomposite & $\mathrm{pH}$ & Loaded drug $(\mathrm{mM})$ & Drug Entrapment efficiency \% \\
\hline $\mathrm{MD}_{3}$ & 5 & 0.0380 & 32.2 \\
$\mathrm{MD}_{3}$ & 5.5 & 0.0511 & 43.3 \\
$\mathrm{MD}_{3}$ & 6 & 0.0668 & 56.6 \\
\hline
\end{tabular}




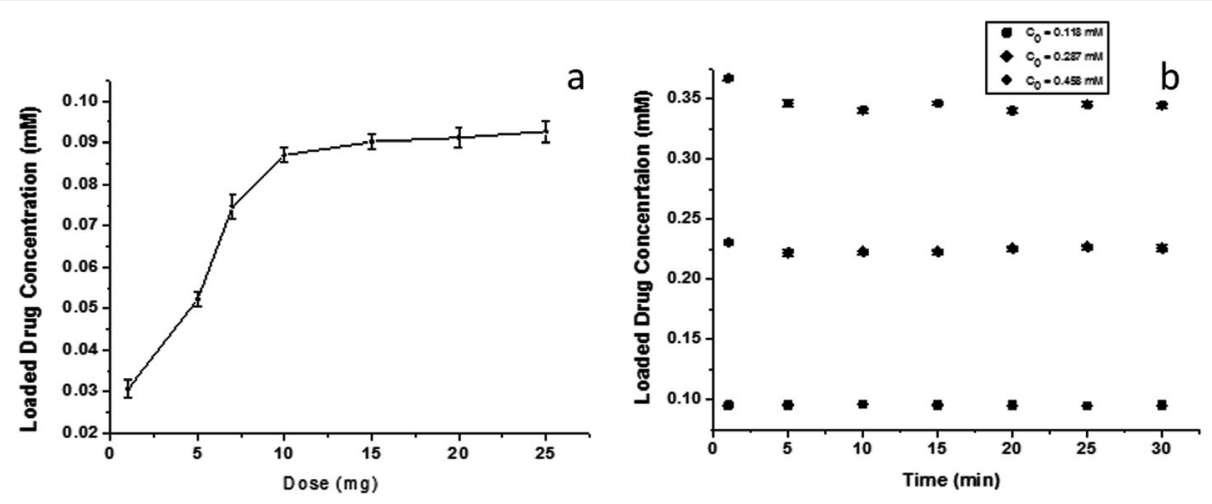

Fig. 8 Loaded drug concentration versus dose onto $\mathrm{MD}_{3}$ (a) and versus time onto $\mathrm{MD}_{3}$ in different drug concentrations (b)

\section{Effect of $\mathrm{pH}$}

As shown in Table 1, $25 \mathrm{mg} \mathrm{MD}_{3}$ and $0.118 \mathrm{mM}$ TPT were taken for interaction in $2 \mathrm{~mL}$ phosphate buffer at

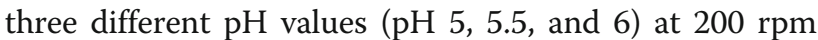
at $25{ }^{\circ} \mathrm{C}$, and the interaction results were given depending on time. Also after each time, the results of remaining concentrations of the lactone and carboxylate forms in the solution and the results of the total loaded drug concentration and loading capacity were shown in Table 1. Accordingly, the increase in $\mathrm{pH}$ not only increased the concentration of the loaded drug but also the remaining concentration of carboxylate form in the medium.

The results of HPLC diagrams for remaining concentrations of lactone and carboxylate form were shown in Fig. $7 \mathrm{a}-\mathrm{c}$ at $\mathrm{pH} 5,5.5$, and 6 . The optimum $\mathrm{pH}$ value for this study was set at $\mathrm{pH} 5$ because the concentration of carboxylate form increased with increasing $\mathrm{pH}$. The toxic effect of the carboxylate form on healthy cells is undesirable. In addition, the first $30 \mathrm{~s}$ of interaction time was considered in this study. As the interaction time increased, the concentration of the carboxylate form remaining in the solution also increased therefore short -time interactions were considered suitable for this study. The TPT was thought to be loaded with physical interactions onto the $\mathrm{MD}_{3}$.
The loaded concentration and loading efficiency (\%) of drug onto the $\mathrm{MD}_{3}$ was given in Table 2 at $\mathrm{pH} 5,5.5$, and 6. According to the Tables 1 and 2, the increase in the $\mathrm{pH}$ caused an increase in both the drug-loaded concentration and the remaining concentration of carboxylate form in the solution.

\section{Dose of $\mathrm{MD}_{3}$ and concentration of TPT}

As can be seen from the Fig. 8a, the concentration of the loaded drug increased when the dose was increased. However, the $\mathrm{MD}_{3}$ nanocomposite was agglomerated in this dose $(25 \mathrm{mg})$. It may be posed a problem ingestion of cellular in cytotoxicity experiments. Therefore, $5 \mathrm{mg}$ was determined as the appropriate dose for this study. It was observed that as the concentration of TPT increased, the loaded drug concentration increased (Fig. 8b). Cytotoxicity studies in the literature related to TPT have generally been performed with drug concentrations at the $\mu \mathrm{M}$ or nM level (Aljuffali et al. 2011; Hormann et al. 2012). Therefore, $0.118 \mathrm{mM}$ TPT was considered suitable for this study.

\section{Release}

Drug release studies were carried out in phosphate buffer with $5 \mathrm{mg}$ nanocomposite at different $\mathrm{pH}$ values (5.8, 6.5, and 7.4) at body temperature. The drug release

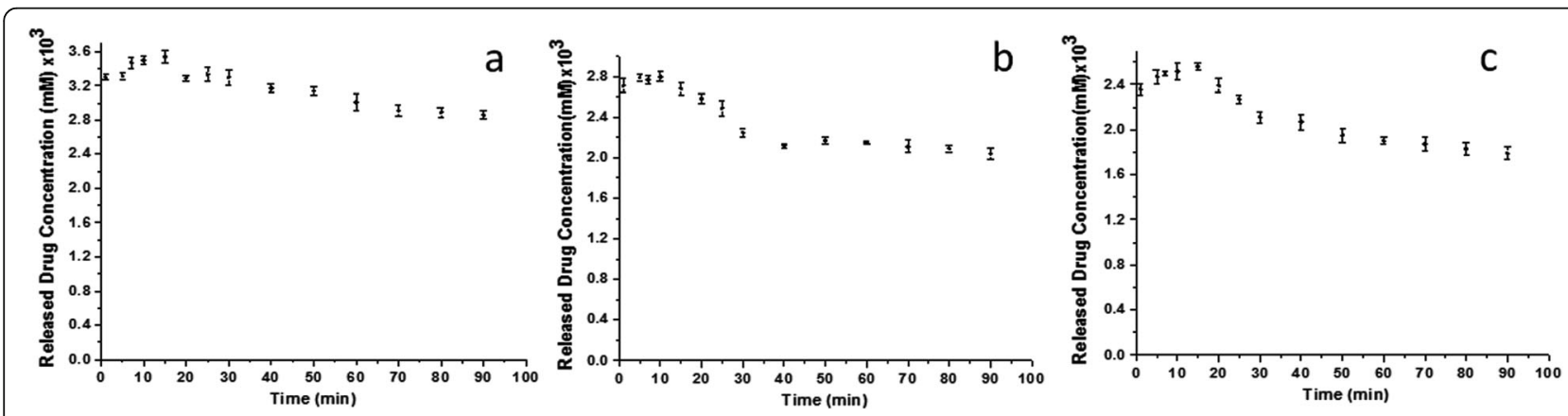

Fig. 9 The drug release results at pH 5.8 (a), 6.5 (b), and 7.4 (c) 
results were shown in Fig. 9 at $\mathrm{pH}$ 5.8, 6.5, and 7.4 respectively. The optimum $\mathrm{pH}$ value for release of drug was found to be 5.8 and the release of TPT was equilibrated after $40 \mathrm{~min}$.

Release of the free and the loaded drug was shown in Fig. 10a, b, respectively. The drug release studies were shown that the loaded drug could stay in active form for a longer time than free drug onto the $\mathrm{MD}_{3}$ nanocomposite.

Drug loading studies were carried out at $\mathrm{pH} 5$ onto $\mathrm{MD}_{3}$ and the release was carried out at $\mathrm{pH} 5.8$ at 36.5 ${ }^{\circ} \mathrm{C}$. The loaded drug concentration was calculated as $0.0380 \mathrm{mM}$ at pH 5 and $0.00092 \mathrm{mM}$ TPT was released after $90 \mathrm{~min}$. The percent of released drug was calculated according to the formula (2) and $2.42 \%$ TPT was released after $90 \mathrm{~min}$.

\section{Conclusion}

In this study, biocompatible, biodegradable, non-toxic, and superparamagnetic $\mathrm{MD}_{3}$ was synthesized for biomedical applications. By increasing the number of carboxyl groups branching to the surface, it was aimed to attach various molecules (e.g., drug, DNA, enzyme, antibody) more easily and effectively to the surface. The nanocomposite was synthesized for biomedical applications and was successfully characterized using different characterization techniques such as FT-IR, XPS, and EDX, and the results were consistent with the literature. The magnetic saturation value of the nanocomposite was measured by VSM and found to be suitable for drug delivery systems and magnetic targeting. In addition, particle sizes and surface morphologies were characterized by TEM and SEM and the particle size of $\mathrm{MD}_{3}$ was measured as 8 $\pm 2.1 \mathrm{~nm}$.

The drug loading yield was found as $32.2 \%$ for the $\mathrm{MD}_{3}$ nanocomposite. Percentage of the drug released was found as $2.42 \%$ during $90 \mathrm{~min}$ and reached equilibrium after $40 \mathrm{~min}$. On the other hand, $\mathrm{MD}_{3}$ was found to have a high drug-loading capacity and also drug loaded onto $\mathrm{MD}_{3}$ could remain in active form in a longer time and higher concentration than free drug. This may be due to the hydrogen bond interactions between the $-\mathrm{COOH}$ groups of $\mathrm{MD}_{3}$ and the hydroxyl groups on the lactone ring. In the $\mathrm{pH}$-dependent drug loading studies, it was found that the lactone form was more stable at $\mathrm{pH} 5$ than higher $\mathrm{pH}$ values. Furthermore, the $\mathrm{pH}$-dependent drug release studies were carried out at different $\mathrm{pH}$ and the stable release has been at $\mathrm{pH} 5.8$ (at the $\mathrm{pH}$ of cancer site). In conclusion, these results show that biocompatible and biodegradable branched magnetic nanocomposite $\left(\mathrm{MD}_{3}\right)$ can be applied as a novel drug-delivery carrier for controlled drug release.

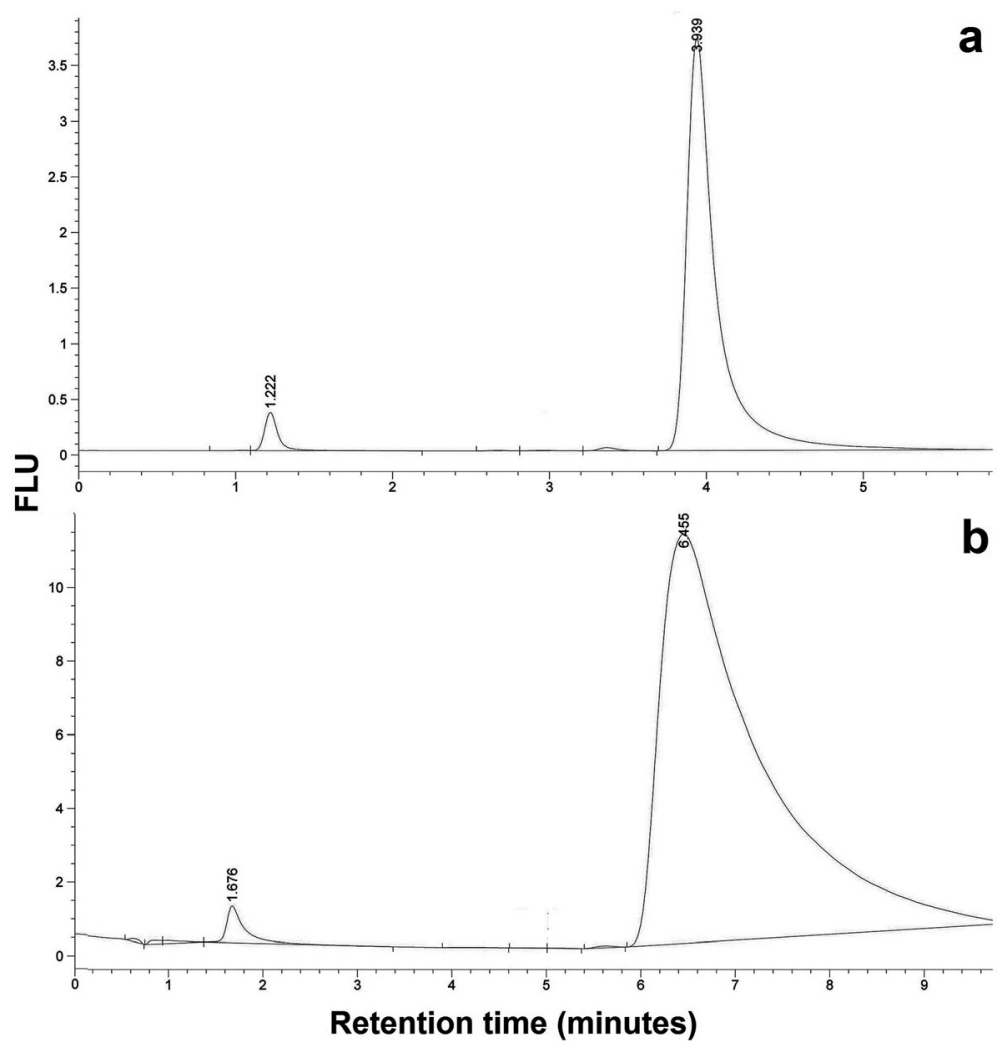

Fig. 10 The release of the free drug (a) and release of the loaded drug on the $\mathrm{MD}_{3}(\mathbf{b})$ 


\section{Abbreviations}

Caco-2: Human epithelium colorectal adenocarcinoma; CMD: Carboxymethyl dextran; CPT: Camptothecin; CPT-11: Irinotecan; EDC: N-(3-dimethyl aminopropyl)-N-ethyl carbodiimide hydrochloride; EDX: Energy dispersive $\mathrm{X}$ ray analysis; FT-IR: Fourier-transform infrared spectroscopy; HAS: Human serum albumin; HPLC: High-performance liquid chromatography; MCF7: Human breast cancer; MD1: Magnetic dextran; MD2: Magnetic Ocarboxymethyl dextran; MD3: New branched magnetic dextran nanocomposite; MNPs: Magnetic nanoparticles; NHS: N-Hydroxysuccinimide NTA: NaNa-Bis (carboxymethyl)-L-lysine hydrate; PACA: Polycyanoacrylate; PCL: Polycaprolactone; PLA: Polylactic acid; PLGA: Polylactic-co-glycolic acid; SEM: Scanning electron microscope; TEM: Transmission electron microscope; TPT: Topotecan; VSM: Vibrating sample magnetometer; XPS: X-ray photoelectron spectroscopy

\section{Acknowledgments}

Not applicable in this section.

\section{Authors' contributions}

TT carried out the experimental studies, and collection, analysis, and interpretation of data and in writing the manuscript should be declared. BT conceived and coordinated of the study and helped to draft the manuscript. ST participated in the design of the study. All authors read and approved the final manuscript.

\section{Funding}

This project is funded by Dicle University Research Fund (DUBAP, Project No. ZGEF.16.008 and 116Z778) and The Scientific and Technological Research Council of Turkey (TUBITAK, 116Z778) for synthesis of materials, characterization, and all analysis study.

\section{Availability of data and materials}

Data sharing not applicable to this article as no datasets were generated or analyzed during the current study.

\section{Competing interests}

The authors declare that they have no competing interests.

\section{Author details}

${ }^{1}$ Vocational Higher School of Health Services, Mardin Artuklu University, Mardin, Turkey. ${ }^{2}$ Department of Chemistry, Faculty of Education, Dicle University, Diyarbakır, Turkey.

Received: 17 June 2019 Accepted: 20 August 2019

Published online: 04 September 2019

\section{References}

Aguirre M, Salazar-Sandoval EJ, Johansson M, Ahniyaz A, Paulis M, Leiza JR. Hybrid acrylic/ $\mathrm{CeO}_{2}$ nanocomposites using hydrophilic, spherical and high aspect ratio $\mathrm{CeO}_{2}$ nanoparticles. J Mater Chem A. 2014;2:20280-7. https://doi. org/10.1039/C4TA03620D.

Ak G. In: University of Ege, editor. Synthesis of folate-peg-doxorubicin conjugate, labelling with technetium and research into its applications as an imaging agent in cancer. Dissertation; 2010.

Aljuffali IA, Mock JN, Costyn LJ, Nguyen H, Nagy T, Cummings BS, Arnold RD. Enhanced antitumor activity of low-dose continuous administration schedules of topotecan in prostate cancer. Cancer Biol Ther. 2011;12:407-20. https://doi.org/10.4161/cbt.12.5.15950.

Anderson J, Kuhn M, Diebold U. Epitaxially grown $\mathrm{Fe}_{3} \mathrm{O}_{4}$ thin films: an XPS study. Surf Sci Spectra. 1996:4:266-72. https://doi.org/10.1116/1.1247796.

Andersson PO, Lundquist M, Tegler L, Börjegren S, Baltzer L, Österlund L. A novel ATR-FTIR approach for characterisation and identification of ex situ immobilised species. Chem Phys Chem. 2007;8:712-22. https://doi.org/10.1 002/cphc.200600691

Ayala V, Herrera AP, Latorre-Esteves M, Torres-Lugo M, Rinaldi C. Effect of surface charge on the colloidal stability and in vitro uptake of carboxymethyl dextran-coated iron oxide nanoparticles. J Nanopart Res. 2013;15:1874. https://doi.org/10.1007/s11051-013-1874-0.

Bertrand R, Solary E, O'Connor P, Kohn KW, Pommier Y. Induction of a common pathway of apoptosis by staurosporine. Exp Cell Res. 1994;211:314-21. https://doi.org/10.1006/excr.1994.1093.
Cao Q, Han X, Li L. Enhancement of the efficiency of magnetic targeting for drug delivery: development and evaluation of magnet system. J Magn Magn Mater. 2011;323:1919-24. https://doi.org/10.1016/j.jmmm.2 010.11.058.

Chellouli M, Chebabe D, Dermaj A, Erramli H, Bettach N, Hajjaji N, Srhiri A. Corrosion inhibition of iron in acidic solution by a green formulation derived from Nigella sativa L. Electrochimica Acta. 2016;204:50-9 https://doi.org/10.1 016/j.electacta.2016.04.015.

Creixell M, Herrera AP, Latorre-Esteves M, Ayala V, Torres-Lugo M, Rinaldi C. The effect of grafting method on the colloidal stability and in vitro cytotoxicity of carboxymethyl dextran coated magnetic nanoparticles. J Mater Chem. 2010; 20:8539-47. https://doi.org/10.1039/COJM01504K.

Danhier F, Feron O, Preat V. To exploit the tumor microenvironment: Passive and active tumor targeting of nanocarriers for anti-cancer drug delivery. J Control Release. 2010;148:135-46. https://doi.org/10.1016/j.jconrel.2010.08.027.

Dumitraşcu M, Meltzer V, Sima E, Virgolici M, Albu M, Ficai A, Scărişoreanu A. Characterization of electron beam irradiated collagen-polyvinylpyrrolidone (PVP) and collagen-dextran (DEX) blends. Dig J Nanomater Biostructures. 2011;6:1793-803.

Fugit $\mathrm{KD}$, Anderson $\mathrm{BD}$. The role of $\mathrm{pH}$ and ring-opening hydrolysis kinetics on liposomal release of topotecan. J Control Release. 2014;174:88-97 https://doi. org/10.1016/j.jconrel.2013.11.003.

Gaucher G, Dufresne MH, Sant VP, Kang N, Maysinger D, Leroux JC. Block copolymer micelles: preparation, characterization and application in drug delivery. J Control Release. 2005;109:169-88. https://doi.org/10.1016/j.jconrel.2005.09.034.

Godo O, Gaskell K, Pathak GK, Kyrtsos CR, Ehrman SH, Shah SB. Characterization of fluorescent iron nanoparticles_candidates for multimodal tracking of neuronal transport. Aims Bioengineering. 2016;3:362-78. https://doi.org/10.3 934/bioeng.2016.3.362.

Goodarzi N, Varshochian R, Kamalinia G, Atyabi F, Dinarvand R. A review of polysaccharide cytotoxic drug conjugates for cancer therapy. Carbohydr Polym. 2013;92:1280-93. https://doi.org/10.1016/j.carbpol.2012.10.036.

Han GC, Ouyang Y, Long XY, Zhou Y, Li M, Liu YN, Kraatz HB. (Carboxymethyldextran)-modified magnetic nanoparticles conjugated to octreotide for MR applications. Eur J Inorg Chem. 2010;2010:5455-61. https://doi.org/10.1002/ ejic.201000715.

Harada M, Sakakibara H, Yano T, Suzuki T, Okuno S. Determinants for the drug release from T-0128, camptothecin analogue-carboxymethyl dextran conjugate. J Control Release. 2000;69:399-412.

Hong RY, Feng B, Chen LL, Liu GH, Li HZ, Zheng Y, Wei DG. Synthesis, characterization and MRI application of dextran-coated $\mathrm{Fe}_{3} \mathrm{O}_{4}$ magnetic nanoparticles. Biochem Eng J. 2008;42:290-300. https://doi.org/10.1016/j.bej.2008.07.009.

Hormann V, Kumi-Diaka J, Durity M, Rathinavelu A. Anticancer activities of genistein-topotecan combination in prostate cancer cells. J Cell Mol Med. 2012;16:2631-6. https://doi.org/10.1111/j.1582-4934.2012.01576.x.

Karlsson HL, Cronholm P, Gustafsson J, Möller L. Copper oxide nanoparticles are highly toxic: a comparison between metal oxide nanoparticles and carbon nanotubes. Chem Res Toxicol. 2008;21:1726-32. https://doi.org/10.1021/ tx800064j.

Kaya M, Mr V. New approach for the surface enhanced resonance Raman scattering (SERRS) detection of dopamine at picomolar (pM) levels in the presence of ascorbic acid. Anal Chem. 2012;84:7729-35. https://doi.org/10.1 021/ac3010428.

Khalkhali M, Sadighian S, Rostamizadeh K, Khoeini F, Naghibi M, Bayat N, Hamidi $M$. Synthesis and characterization of dextran coated magnetite nanoparticles for diagnostics and therapy. Biolmpacts: BI. 2015;5:141. https://doi.org/10.151 71/bi.2015.19.

Kim DK, Zhang Y, Voit W, Rao KV, Muhammed M. Synthesis and characterization of surfactant-coated superparamagnetic monodispersed iron oxide nanoparticles. J Magn Magn Mater. 2001;225:30-6 https://doi.org/10.1016/ S0304-8853(00)01224-5.

Koneracká M, Antošová A, Závišová V, Lancz G, Gažová Z, Šipošováa K, Tomašovičová N. Characterization of $\mathrm{Fe}_{3} \mathrm{O}_{4}$ Magnetic nanoparticles modified with dextran and investigation of their interaction with protein amyloid aggregates. Acta Phys Pol A. 2010;118:983-5. https://doi.org/10.12693/ APhysPolA.118.983.

Lee ES, Na K, Bae YH. Super pH-sensitive multifunctional polymeric micelle. Nano Lett. 2005:5:325-9. https://doi.org/10.1021/nl0479987.

Lee J, Cho EC, Cho K. Incorporation and release behavior of hydrophobic drug in functionalized poly(D,L-lactide)-block-poly(ethylene oxide) micelles. J Control Release. 2004;94:323-35 https://doi.org/10.1016/j.jconrel.2003.10.012. 
Lee KJ, An JH, Shin JS, Kim DH, Yoo HS, Cho CK. Biostability of $\mathrm{y}$-Fe2O3 nano particles Evaluated using an in vitro cytotoxicity assays on various tumor cell lines. Curr Appl Phys. 2011;11:467-71. https://doi.org/10.1016/j.cap.2010.08.022.

Li J, Zhou Y, Li M, Xia N, Huang Q, Do H, Zhou F. Carboxymethylated dextran-coated magnetic iron oxide nanoparticles for regenerable bioseparation. J Nanosci Nanotechnol. 2011;11:10187-92. https://doi.org/10.1166/jnn.2011.5002.

Liu Y, Jiang W, Li S, Li F. Electrostatic self-assembly of $\mathrm{Fe}_{3} \mathrm{O}_{4}$ nanoparticles on carbon nanotubes. Appl Surf Sci. 2009;255:7999-8002 https://doi.org/10.1016/ j.apsusc.2009.05.002.

Mclntosh DP, Cooke RJ, McLachlan AJ, Daley-Yates PT, Rowland M. Pharmacokinetics and tissue distribution of cisplatin and conjugates of cisplatin with carboxymethyldextran and A5B7 monoclonal antibody in CD1 mice. J Pharm Sci. 1997;86:1478-83. https://doi.org/10.1021/js960282u.

Mert O, Esendağlı G, Doğan AL, Demir AS. Injectable biodegradable polymeric system for preserving the active form and delayed-release of camptothecin anticancer drugs. RSC Advances. 2012;2:176-85. https://doi.org/10.1039/C1 RA00366F.

Mojarradi $\mathrm{H}$. Coupling of substances containing a primary amine to hyaluronan via carbodiimide-mediated amidation. Dissertation, University of Uppsala. 2011

Nath S, Kaittanis C, Ramachandran V, Dalal NS, Perez JM. Synthesis, magnetic characterization, and sensing applications of novel dextran-coated iron oxide nanorods. Chem Mater. 2009;21:1761-7 https://doi.org/10.1021/cm8031863.

Neuberger T, Schöpf B, Hofmann H, Hofmann M, von Rechenberg B. Superparamagnetic nanoparticles for biomedical applications: possibilities and limitations of a new drug delivery system. J Magn Magn Mater. 2005; 293:483-96. https://doi.org/10.1016/j.jmmm.2005.01.064.

Ogris M, Wagner E. Targeting tumors with non-viral gene delivery systems. Drug Discov Today. 2002;7:479-85. https://doi.org/10.1016/S1359-6446(02)02243-2.

Park JH, Im KH, Lee SH, Kim DH, Lee DY, Lee YK, Kim KN. Preparation and characterization of magnetic chitosan particles for hyperthermia application. J Magn Magn Mater. 2005;293:328-33. https://doi.org/10.1016/j.jmmm.2005. 02.027 .

Park JH, Lee S, Kim JH, Park K, Kim K, Kwon IC. Polymeric nanomedicine for cancer therapy. Prog Polym Sci. 2008;33:113-37. https://doi.org/10.1016/j. progpolymsci.2007.09.003.

Pisanic TR, Blackwell JD, Shubayev VI, Fiñones RR, Jin S. Nanotoxicity of iron oxide nanoparticle internalization in growing neurons. Biomaterials. 2007;28:257281. https://doi.org/10.1016/j.biomaterials.2007.01.043.

Pommier Y. Topoisomerase I inhibitors: camptothecins and beyond. Nat Rev Cancer. 2006;6:789-802. https://doi.org/10.1038/nrc1977.

Pommier $Y$, Leo E, Zhang H, Marchand C. DNA topoisomerases and their poisoning by anticancer and antibacterial drugs. Chem Biol. 2010;17:421-33. https://doi.org/10.1016/j.chembiol.2010.04.012.

Rodriguez-Luccioni HL, Latorre-Esteves M, Mendez-Vega J, Soto O, Rodriguez AR, Rinaldi C, Torres-Lugo M. Enhanced reduction in cell viability by hyperthermia induced by magnetic nanoparticles. Int J Nanomedicine. 2011; 6:373-80. https://doi.org/10.2147/ijn.s14613.

Schweiger C, Pietzonka C, Heverhagen J, Kissel T. Novel magnetic iron oxide nanoparticles coated with poly(ethylene imine)-g-poly(ethylene glycol) for potential biomedical application: synthesis, stability, cytotoxicity and MR imaging. Int J Pharm. 2011;408:130-7. https://doi.org/10.1016/j.jpharm.201 0.12 .046 .

Shahnaz G, Perera G, Sakloetsakun D, Rahmat D, Bernkop-Schnürch A. Synthesis, characterization, mucoadhesion and biocompatibility of thiolated carboxymethyl dextran-cysteine conjugate. J Control Release. 2010;144:32-8. https://doi.org/10.1016/j.jconrel.2010.01.033.

Singh N, Jenkins GJ, Nelson BC, Marquis BJ, Maffeis TG, Brown AP, Doak SH. The role of iron redox state in the genotoxicity of ultrafine superparamagnetic iron oxide nanoparticles. Biomaterials. 2012;33:163-70. https://doi.org/10.1 016/j.biomaterials.2011.09.087.

Souaya E, Hanna W, Ismail E, Milad N. Studies on some acid divalent-metal nitrilotriacetate complexes. Molecules. 2000;5:1121-9. https://doi.org/10.33 90/51001121.

Staker BL, Hjerrild K, Feese MD, Behnke CA, Burgin AB Jr, Stewart L. The mechanism of topoisomerase I poisoning by a camptothecin analog. Proc Natl Acad Sci USA. 2002;99:15387-92. https://doi.org/10.1073/ pnas.242259599.

Sun H, Guo B, Li X, Cheng R, Meng F, Liu H, Zhong Z. Shell-sheddable micelles based on dextran-SS-poly(epsilon-caprolactone) diblock copolymer for efficient intracellular release of doxorubicin. Biomacromolecules. 2010;11:84854. https://doi.org/10.1021/bm1001069.
Tarhan T, Tural B, Tural S, Topal G. Enantioseparation of mandelic acid enantiomers with magnetic nano-sorbent modified by a chiral selector. Chirality. 2015;(11):835-42. https://doi.org/10.1002/chir.22524.

Thambi T, You DG, Han HS, Deepagan VG, Jeon SM, Suh YD, Park JH. Bioreducible carboxymethyl dextran nanoparticles for tumor-targeted drug delivery. Adv Healthc Mater. 2014;3:1829-38. https://doi.org/10.1002/adhm.2 01300691.

Thomas LA. Nanoparticle Synthesis For Magnetic Hyperthermia. Dissertation, University of College London. 2010.

Torchilin VP. PEG-based micelles as carriers of contrast agents for different imaging modalities. Adv Drug Deliv Rev. 2002;54:235-52 https://doi.org/10.1 016/S0169-409X(02)00019-4.

Tural B, Kaya M, Özkan N, Volkan M. Preparation and Characterization of NiNitrilotriacetic Acid Bearing Poly(Methacrylic Acid) Coated Superparamagnetic Magnetite Nanoparticles. J Nanosci Nanotechnol. 2008;8: 695-701. https://doi.org/10.1166/jnn.2008.B270.

Unsoy G, Yalcin S, Khodadust R, Gunduz G, Gunduz U. Synthesis optimization and characterization of chitosan-coated iron oxide nanoparticles produced for biomedical applications. J Nanopart Res. 2012;14:964. https://doi.org/10.1007/ s11051-012-0964-8.

Wang C, Luo H, Zhang Z, Wu Y, Zhang J, Chen S. Removal of As (III) and As (V) from aqueous solutions using nanoscale zero valent iron-reduced graphite oxide modified composites. J Hazard Mater. 2014;268:124-31 https://doi. org/10.1016/j.jhazmat.2014.01.009.

Wu Y, Zhang T, Zheng Z, Ding X, Peng Y. A facile approach to $\mathrm{Fe}_{3} \mathrm{O}_{4} @ A u$ nanoparticles with magnetic recyclable catalytic properties. Mater Res Bull. 2010;45:513-7 https://doi.org/10.1016/j.materresbull.2009.11.012.

Xie DL, Hu Y, Shen QD, Yang CZ. Study of polyfunctional carboxyl telechelic microspheres. J Appl Polym Sci. 1999;72:667-76 https://doi.org/10.1002/ (SICI)1097-4628(19990502)72:5<667::AID-APP7>3.0.CO;2-E.

Xing Y, Jin YY, Si JC, Peng ML, Wang XF, Chen C, Cui YL. Controllable synthesis and characterization of $\mathrm{Fe}_{3} \mathrm{O}_{4} / \mathrm{Au}$ composite nanoparticles. J Magn Magn Mater. 2015;380:150-6 https://doi.org/10.1016/j.jmmm.2014.09.060.

Zhang H, Sun Y, Wang J, Zhang J, Zhang H, Zhou H, Song D. Preparation and application of novel nanocomposites of magnetic-Au nanorod in SPR biosensor. Biosens Bioelectron. 2012;34:137-43 https://doi.org/10.1016/j.bios.2 012.01.032.

Zhang K, Zheng H, Liang S, Gao C. Aligned PLLA nanofibrous scaffolds coated with graphene oxide for promoting neural cell growth. Acta biomater. 2016; 37:131-42 https://doi.org/10.1016/j.actbio.2016.04.008.

Zhang L, Yang M, Wang Q, Li Y, Guo R, Jiang X, Liu B. 10-Hydroxycamptothecin loaded nanoparticles: preparation and antitumor activity in mice. J Control Release. 2007;119:153-62. https://doi.org/10.1016/j.jconrel.2007.02.013.

Zheng X, Huang T, Pan Y, Wang W, Fang G, Ding K, Wu M. 3, 3'sulfonyldipropionitrile: a novel electrolyte additive that can augment the highvoltage performance of LiNi1/3Co1/3Mn1/3O2/graphite batteries. J Power Sources. 2016;319:116-23. https://doi.org/10.1016/j.jpowsour.2016.04.053.

Zhou H, Tao K, Ding J, Zhang Z, Sun K, Shi W. A general approach for providing nanoparticles water-dispersibility by grinding with poly (ethylene glycol). Colloids Surf Physicochem Eng Aspects. 2011;389:18-26. https://doi.org/10.1 016/j.colsurfa.2011.08.055.

Zhu A, Yuan L, Jin W, Dai S, Wang Q, Xue Z, Qin A. Polysaccharide surface modified $\mathrm{Fe}_{3} \mathrm{O}_{4}$ nanoparticles for camptothecin loading and release. Acta Biomater. 2009;5:1489-98. https://doi.org/10.1016/j.actbio.2008.10.022.

\section{Publisher's Note}

Springer Nature remains neutral with regard to jurisdictional claims in published maps and institutional affiliations. 